\title{
A Novel Ho(III) Sensor based on $N, N$ '-Bis(2- pyridinecarboxamide)-1,2-benzene as a Neutral Ion Carrier
}

\author{
Mohammad Reza Ganjali, ${ }^{*, a}$ Solmaz Rasoolipour, ${ }^{a}$ Morteza Rezapour, ${ }^{a}$ Parviz Norouzi, ${ }^{a}$ \\ Mehdi Amirnasr ${ }^{b}$ and Soraia Meghdadi ${ }^{b}$ \\ ${ }^{a}$ Center of Excellence in Electrochemistry, Faculty of Chemistry, Tehran University, Tehran, Iran \\ ${ }^{b}$ Department of Chemistry, Isfahan University of Technology, Isfahan 84156-83111, Iran
}

\begin{abstract}
$N, N^{\prime}$-bis(2- piridinacarboxamida)-1,2-benzeno ( $\mathrm{H}_{2} \mathrm{BPB}$ ) apresentou um comportamento seletivo e sensível, frente ao íon Ho(III), em comparação a um grande número de íons de metais de transição interna, representativos e de lantanídeos, tendo sido portanto, aplicado como um ionóforo neutro para preparação de uma membrana sensora Ho(III), com alta seletividade e sensitividade. As membranas também contêm tetraquis ( $p$-clorofenil) borato de potássio (KTpClPB) como um aditivo aniônico, e foram testadas pelo uso de diferentes solventes mediadores plastificantes, tais como benzil acetato (BA), nitrobenzeno (NB), e éter $o$-nitrofeniloctil (NPOE). A composição ótima encontrada foi $\mathrm{H}_{2} \mathrm{BPB}-\mathrm{PVC}$ - KTpClPB-BA, com razão de 6,0: 30,0: 4,0: 60,0 , respectivamente. Com uma resposta Nernstiniana de 19,6 0,2 $\mathrm{mV}$ per década de atividade de $\mathrm{Ho}(\mathrm{III})$, o intervalo linear encontrado para o sensor foi relativamente grande (de $1,0 \times 10^{-5}$ a 1,0 $\times 10^{-2} \mathrm{~mol} \mathrm{~L}^{-1}$ ), podendo trabalhar bem no intervalo de $\mathrm{pH}$ de 3,0 a 11,5. O limite de detecção mais baixo (LDL) calculado para o sensor foi de $8,0 \times 10^{-6} \mathrm{~mol} \mathrm{~L}^{-1}$. A excelente seletividade do sensor proposto para Ho(III), considerando os íons metálicos mais comuns e, especialmente todos os íons lantanídeos, é uma outra vantagem deste sensor. O sensor foi usado com sucesso como eletrodo indicador na titulação de $25 \mathrm{~mL}$ de solução de íons Ho(III) a $1,0 \times 10^{-4} \mathrm{~mol} \mathrm{~L}^{-1}$, com EDTA a $1,0 \times 10^{-2} \mathrm{~mol} \mathrm{~L}^{-1}$, e vice-versa. Este é o primeiro sensor seletivo para $\mathrm{Ho}(\mathrm{III})$.
\end{abstract}

$N, N^{\prime}$-bis(2- pyridinecarboxamide)-1,2-benzene ( $\left.\mathrm{H}_{2} \mathrm{BPB}\right)$ was found to have a selective and sensitive behavior towards Ho(III) ion, in comparison to a large number of lanthanide, inner transition and representative metal ions and was hence applied as a neutral ionophore, for preparing an Ho(III) membrane sensor, with high selectivity and sensitivity. The membranes, also contain potassium tetrakis( $p$-chlorophenyl) borate as an anionic additives, and were tested by using different plasticizing solvent mediators such as benzyl acetate (BA), nitrobenzene (NB), and $o$-nitrophenyloctyl ether (NPOE). The optimum composition was found to be $\mathrm{H}_{2} \mathrm{BPB}-\mathrm{PVC}-\mathrm{KTpClPB}-\mathrm{BA}$ with the ratios of 6.0: 30.0: 4.0: 60.0, respectively. Having a Nernstian response of $19.6 \pm 0.2 \mathrm{mV}$ per decade of $\mathrm{Ho}$ (III) activity, the linear range of the sensor was found to be relatively wide (from $1.0 \times 10^{-5}$ to 1.0 $\times 10^{-2} \mathrm{~mol} \mathrm{~L}^{-1}$ ). It can work well in the $\mathrm{pH}$ range of 3.0-11.5. The lower detection limit (LDL) of the sensor was calculated to be $8.0 \times 10^{-6} \mathrm{~mol} \mathrm{~L}^{-1}$. The excellent $\mathrm{Ho}$ (III)-selectivity of the proposed sensor with regard to most common metal ions, and especially, all lanthanide ions, is another advantage that can be mentioned about this sensor. The sensor was successfully used as an indicator electrode for titration of $25 \mathrm{~mL}$ of a $1.0 \times 10^{-4} \mathrm{~mol} \mathrm{~L}^{-1} \mathrm{Ho}$ (III) ions with a $1.0 \times 10^{-2} \mathrm{~mol} \mathrm{~L}^{-1}$ EDTA, and vise versa. To the best of our knowledge this is the first Ho(III)-selective sensor.

Keywords: Ho(III), ion selective electrode, PVC, $N, N^{\prime}$-bis(2-pyridinecarboxamide)-1,2- benzene

\section{Introduction}

Holmium, being a rare earth, can absorb fission-bored, so is used in nuclear reactors to keep a chain reaction under control. Its very high magnetic moment makes it

*e-mail: Ganjali@khayam.ut.ac.ir suitable for use in yttrium-iron-garnet (YIG) and yttriumlanthanum-fluoride (YLF) solid-state lasers found in microwave equipment (which are in turn found in a variety of medical and dental settings). It is one of the rare earths that can be found in equipment such as color televisions, fluorescent lamps, energy-saving lamps and glasses. The use of holmium is still growing, due to the fact that it is 
studied to produce catalysts and to polish glass. ${ }^{1}$ Holmium can be a threat to the liver when it accumulates in the human body. Today we know that with water animals, holmium causes damage to cell membranes, which has several negative influences on reproduction the functions of the nervous system. This makes the analysis of this element greatly important. However conventional methods that can be used for the analysis of this element, such as ICP-AES, neutron activation analysis, are either expensive or difficult to work with. Hence the ability to analyze this element in different matrixes is of great importance.

The recent introduction of a number of lanthanide selective membrane sensors for $\mathrm{La}(\mathrm{III}), \mathrm{Ce}(\mathrm{III}), \mathrm{Gd}(\mathrm{III})$, Sm(III), Eu(III), Dy(III), and Yb(III) ions based on different noncyclic and macrocyclic ionophore, by our own and other groups, ${ }^{2-28}$ inspired us to try the construction of a $\mathrm{Ho}(\mathrm{III})$-selective electrode based on $\mathrm{a}_{2} \mathrm{BPB}$ as an ion carrier. The resulting electrode shows to be suitable for the determination of $\mathrm{Ho}$ (III) concentration in the range of $1.0 \times 10^{-5}-1.0 \times 10^{-2} \mathrm{~mol} \mathrm{~L}^{-1}$, with a lower detection limit of $8.0 \times 10^{-6} \mathrm{~mol} \mathrm{~L}^{-1}$ and within $\mathrm{pH}$ values between 3.0-11.5. To the best our knowledgements this is the first report on Ho(III) sensor.

\section{Experimental}

\section{Reagents}

Reagent grade benzyl acetate (BA), nitrobenzene (NB), $o$-nitrophenyloctyl ether (NPOE), high relative molecular weight PVC, tetrakis( $p$-chlorophenyl) borate (KTpClPB), and tetrahydrofurane (THF) were purchased from Aldrich and used as received. Chloride and nitrate salts of the cations used (from Merck and Aldrich) were of the highest purity available and used without any further purification except for vacuum drying over $\mathrm{P}_{2} \mathrm{O}_{5}$. Triply distilled deionized water was used through out. $\mathrm{H}_{2} \mathrm{BPB}$ was synthesized by a famous method in the literature. ${ }^{29}$

\section{Electrode preparation}

To prepare the electrodes $30 \mathrm{mg}$ of powdered PVC, $60 \mathrm{mg}$ of BA and $6 \mathrm{mg}$ of additive KTpClPB were dissolved in $3 \mathrm{~mL}$ of THF, and $6 \mathrm{mg}$ of $\mathrm{H}_{2} \mathrm{BPB}$ was added to the resulting solution, which had a low viscosity. After completely mixing the solution it was transferred into a glass dish of $2 \mathrm{~cm}$ diameter, and then its solvent was let evaporate so as to gain an oily concentrated mixture. The membrane was then formed on the tip of a Pyrex tube of (3-5 mm o.d.), by inserting the tube into the viscose mixture for about $10 \mathrm{~s}$, so that a transparent membrane of about $0.3 \mathrm{~mm}$ thickness was formed. Before being filled with an internal filling solution $\left(1.0 \times 10^{-3} \mathrm{~mol} \mathrm{~L}^{-1} \mathrm{HoCl}_{3}\right)$, the tube was pulled out and given enough time to dry at room temperature for about $10 \mathrm{~h}$. The final step was to condition the electrode for $24 \mathrm{~h}$, by soaking in a $1.0 \times 10^{-3} \mathrm{~mol} \mathrm{~L}^{-1}$ $\mathrm{Ho}\left(\mathrm{NO}_{3}\right)_{3}$ solution. A Silver/ Silver chloride coated wire was used as an internal reference electrode.

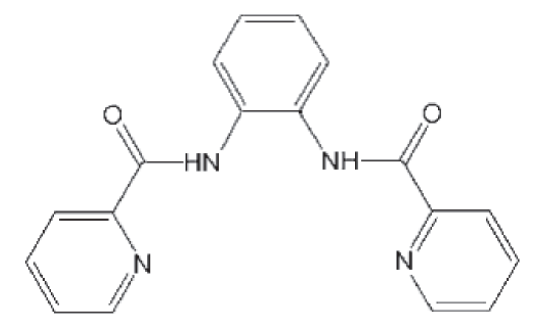

Figure 1. Structure of $\mathrm{H}_{2} \mathrm{BPB}$.

\section{EMF measurements}

The cell assembly $\mathrm{Ag}-\mathrm{AgCl} /$ internal solution $\left(1.0 \times 10^{-3}\right.$ mol L-1 $\mathrm{HoCl}_{3}$ ) / PVC Membrane / test solution / $\mathrm{Hg}_{2} \mathrm{Cl}_{2}$, $\mathrm{KCl}$ (satd.) was used for all measurements.

All potential measurements were carried out by means of a Corning ion analyzer $250 \mathrm{pH} / \mathrm{mV}$ meter at $25.0 \pm 0.1{ }^{\circ} \mathrm{C}$.

\section{Results and Discussion}

Regarding that some neutral ion carriers, containing nitrogen and sulfur donor atoms, have been reported, to be used in construction of highly selective transition and heavy metal ion membrane sensors, lately ${ }^{2-28}$ and considering the existence of four nitrogen donor atoms in the semi cavity of $\mathrm{H}_{2} \mathrm{BPB}$, it was expected to act as a suitable ion carrier for special transition and heavy metal ions (specially, higher charge density), in the PVC membranes.

To investigate the possible ions towards which, $\mathrm{H}_{2} \mathrm{BPB}$ is selective, during the initial experiments this carrier was used in the construction of membrane sensors for lanthanide ions liker $\mathrm{Er}^{3+}, \mathrm{La}^{3+}, \mathrm{Pr}^{3+}, \mathrm{Sm}^{3+}, \mathrm{Dy}^{3+}, \mathrm{Ho}^{3+}$, $\mathrm{Tm}^{3+}, \mathrm{Nd}^{3+}$, and other representative and transition metal ions like $\mathrm{Na}^{+}, \mathrm{K}^{+}, \mathrm{Ca}^{2+}, \mathrm{Mg}^{2+}, \mathrm{Pb}^{2+}, \mathrm{Cu}^{2+}$ ions. The curves of the best potential responses of the resulting membranes vs. changing the concentration of each ion, that are shown in Figure 2(a, b), revealed that among the lanthanide, transition and representative ions tested, Ho(III) with the most Nernstian response, can be suitably determined with the PVC membrane sensor based on $\mathrm{H}_{2} \mathrm{BPB}$. 
This behavior may be considered to be the result of the selective tendency of the ionophore against $\mathrm{Ho}(\mathrm{III})$ (with relatively low charge density and hydration energy), in comparison to other metal ions, and the rapid exchange kinetics of the resulting $\mathrm{H}_{2} \mathrm{BPB}-\mathrm{Ho}(\mathrm{III})$ complex.
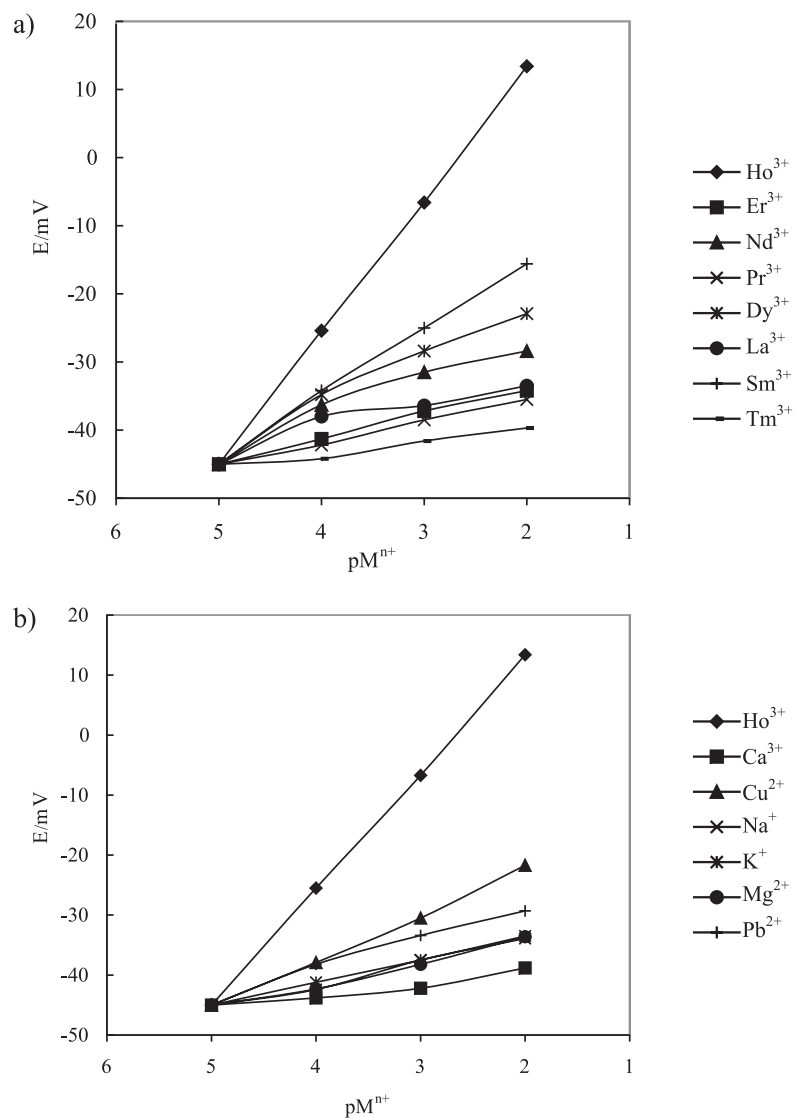

Figure 2. (a) and (b) Potential response various metal ion-selective electrodes based on $\mathrm{H}_{2} \mathrm{BPB}$.

Because the sensitivity and selectivity of any given membrane sensor is significantly related to, the composition of the ion selective membrane, and the nature of the solvent mediators and additives used, ${ }^{2-28,30,31}$ we decided to study such effects on the behavior of the proposed sensor. The effect of the nature and amount of the plasticizer and the additive on the potential response of the proposed Ho(III) sensor were investigated, and the results are summarized in Table 1. These data revealed that the three different plasticizers used, BA, NB, and o-NPOE have almost the same results if the optimum composition is used, however, because $\mathrm{NB}$, and $o$-NPOE are very polar, leading to the extraction of the polar interfering ions such as other rare earth ions which may have negative effects on the selectivity behavior of the sensor, BA was chosen as the solvent mediator. This may to lead to the poorer extraction of Ho(III) ion, that has very high charge density, by the average-polar solvent. However, considering the experimental results, it seems that this effect is compensated by the selective complexation of $\mathrm{H}_{2} \mathrm{BPB}$ with the $\mathrm{Ho}(\mathrm{III})$ ions. This way, not only was the slope of the sensor response maintained, but its selectivity pattern was also improved.

In addition, one can understand from the data in Table 1 that increasing the amount of the ion carrier, up to a value of $6 \%$, increases the sensitivity, while the slope of the resulting emf $v s . \log \mathrm{Ho}(\mathrm{III})$ concentration plot is about two-thirds of the expected Nernstian value (membranes No. 2). However, addition of $4 \% \mathrm{KTpCIPB} \mathrm{(membranes} \mathrm{No.} \mathrm{5)}$ will increase the sensitivity of the electrode response to a great extent. The fact that the presence of lipophilic anions in the composition of cationic-selective membrane sensors, not only diminishes the ohmic resistance and enhances the potential behavior and selectivity, but also in poor extraction capacities, increases the sensitivity of the membrane electrodes, has long been known. ${ }^{32}$

The potential response of the sensor was evaluated using the optimum composition of all ingredients, while lacking the ionophore, and it was found that under these conditions the response of the sensors falls to very low values of 6.2 $\mathrm{mV}$ decade $^{-1}$, indicating that the sensitivity of the sensor is majorly due to the complexing behavior of $\mathrm{H}_{2} \mathrm{BPB}$.

The optimum equilibration time for the membrane electrode, after which it generates stable potentials when placed in contact with $\mathrm{Ho}$ (III) solutions, is found to be $20 \mathrm{~h}$.

Table 1. Optimization of membrane ingredients

\begin{tabular}{|c|c|c|c|c|c|}
\hline \multirow[t]{2}{*}{ Membrane } & \multirow[b]{2}{*}{$\mathrm{PVC}$} & \multicolumn{3}{|c|}{ Composition / (\%) } & \multirow{2}{*}{$\begin{array}{c}\text { Slope / } \\
\left(\mathrm{mV} \text { decade }^{-1}\right)\end{array}$} \\
\hline & & Plasticizer & $\mathrm{H}_{2} \mathrm{BPB}$ & Additive & \\
\hline 1 & 30 & $65, \mathrm{BA}$ & 5 & - & $10.1 \pm 0.3$ \\
\hline 2 & 30 & $64, \mathrm{BA}$ & 6 & - & $10.5 \pm 0.7$ \\
\hline 3 & 30 & $62, \mathrm{BA}$ & 5 & 4, КТрClPB & $14.3 \pm 0.3$ \\
\hline 4 & 30 & $61, \mathrm{BA}$ & 5 & 5, КТрClPB & $16.8 \pm 0.2$ \\
\hline 5 & 30 & $60, \mathrm{BA}$ & 6 & 4, КТрClPB & $19.6 \pm 0.2$ \\
\hline 6 & 30 & $65, \mathrm{BA}$ & - & 5, КТрClPB & $5.0 \pm 0.3$ \\
\hline 7 & 30 & $60, \mathrm{NB}$ & 6 & 4, КТрClPB & $18.7 \pm 0.2$ \\
\hline 8 & 30 & 60, NPOE & 6 & 4, КТрClPB & $19.1 \pm 0.3$ \\
\hline
\end{tabular}




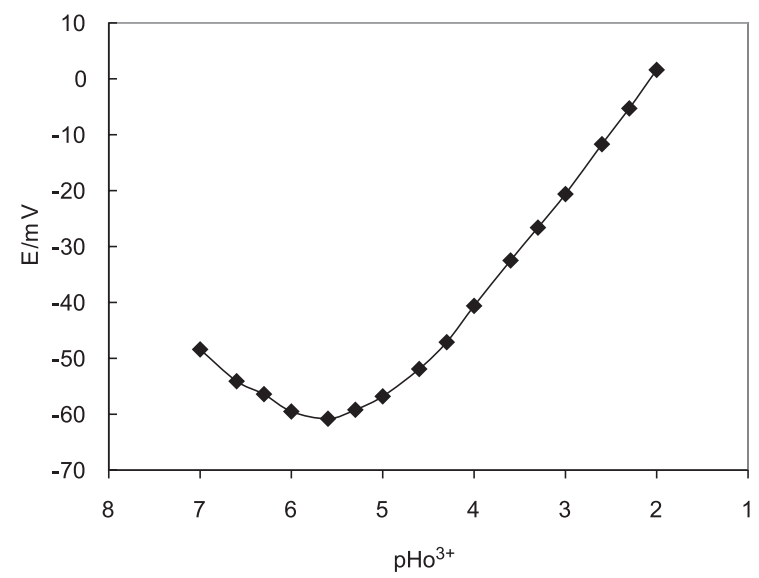

Figure 3. Calibration curve of the Ho(III) sensor of membrane.

The critical response characteristics of the Ho(III) sensor were assessed according to IUPAC recommendations. ${ }^{33}$ The potential response of the membrane at varying concentration of $\mathrm{Ho}(\mathrm{III})$ ions (Figure 3 ) indicates a rectilinear range from $1.0 \times 10^{-5}-1.0 \times 10^{-2} \mathrm{~mol} \mathrm{~L}^{-1}$. The slopes of the calibration curves were $19.6 \pm 0.2 \mathrm{mV}$ decade $^{-1}$ of Ho(III) concentration. The limit of detection, as determined from the intersection of the two extrapolated segments of the calibration graph, was $8.0 \times 10^{-6} \mathrm{~mol} \mathrm{~L}^{-1}$.

The influence of $\mathrm{pH}$ on the response of the membrane sensor to $1.0 \times 10^{-4} \mathrm{~mol} \mathrm{~L}^{-1}$ and $1.0 \times 10^{-3}$ mol L $\mathrm{L}^{-1} \mathrm{Ho}(\mathrm{III})$ solutions, was studied over a $\mathrm{pH}$ range of 1.5 to 13.0, and the results are shown in Figure 4. For the $1.0 \times 10^{-4} \mathrm{~mol} \mathrm{~L}^{-1} \mathrm{Ho}$ (III) solution the potential does not change with changing $\mathrm{pH}$ the $\mathrm{pH}$ range of 3.0 to 11.5 , that indicates the applicability of this sensor in the mentioned $\mathrm{pH}$ range. Beyond these limits, however, relatively drastic drifts in the potential vs. $\mathrm{pH}$ behavior were observed. The observed drift at the higher $\mathrm{pH}$ values of this range could be due to the formation of insoluble $\mathrm{Ho}(\mathrm{OH})_{3}$ in the solution. In acidic solutions having $\mathrm{pH}$ values of less than the minimum of this range, the ionophore used could be protonated to some extent, which results in improper functioning of the membrane electrode to the Ho(III) ion concentration. This can be further justified by the second curve, namely that of a $1.0 \times 10^{-3} \mathrm{~mol} \mathrm{~L}^{-1} \mathrm{Ho}$ (III) solution. In this case slight changes in the applicability range of the sensor are observed and the potential is $\mathrm{pH}$ independent in the range of 2.5-10.5. This supports the fact that the formation of insoluble $\mathrm{Ho}(\mathrm{OH})_{3}$ species that takes place at relatively lower $\mathrm{pH}$ values (10.5 instead of 11.5 in the former case) may be responsible for the potential drifts at higher $\mathrm{pH}$ values. It is also evident that at a relatively higher $\mathrm{Ho}$ (III) concentration,

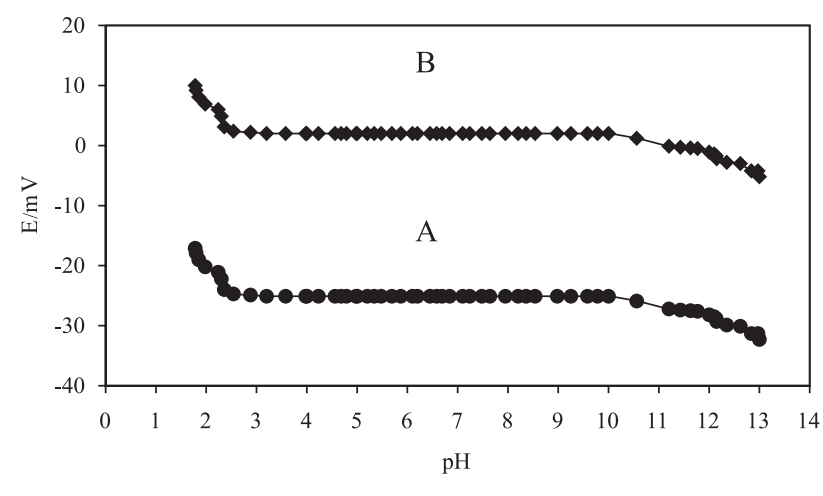

Figure 4. Effect of the $\mathrm{pH}$ of test solution $\left(\mathrm{A}=1.0 \times 10^{-4} \mathrm{~mol} \mathrm{~L}^{-1}\right.$, and $\left.\mathrm{B}=1.0 \times 10^{-3} \mathrm{~mol} \mathrm{~L}^{-1}\right)$ on the potential response of the Ho(III) ion-selective electrode.

the target ions tend to compete more seriously with the proton ions at lower $\mathrm{pH}$ values which extends the applicability $\mathrm{pH}$ range of the sensor at to a value of 2 (rather than 3 in the case of the more dilute solution of $1 \times 10^{-4} \mathrm{~mol} \mathrm{~L}^{-1}$ solution).

The lifetime of the sensor, which is a measure of sensors durability, was also studied in a 4 months period. During this period the sensor was used for 2 hours a day, 5 days a week. After each usage it was washed completely. After three months only a relatively slight change in the sensor's slope and detection limit from $19.6 \pm 0.2 \mathrm{mV}$ decade $^{-1}$ of $\mathrm{Ho}$ (III) concentration and $8 \times 10^{-6} \mathrm{~mol} \mathrm{~L}^{-1}$ to 17.1 $\pm 0.4 \mathrm{mV} \mathrm{decade}^{-1}$ of $\mathrm{Ho}$ (III) concentration and $5 \times$ $10^{-5} \mathrm{~mol} \mathrm{~L}^{-1}$ was observed. The results of this study are shown in Table 3.

One of the most important characteristics of any membrane sensor is its relative response for the primary ion over other ions present in solution, usually expressed in terms of potentiometric selectivity coefficients. In this work, matched potential and separated solution methods (MPM and SSM) ${ }^{35}$ were used for determination of selectivity coefficients of the sensor. According to the general procedure for the determination of the matched potential method a specified amount of the target ion solution is added to a reference solution and the membrane potential is measured. In another experiment, known amounts of different interfering ion solutions are successively added to an identical reference solution until the membrane potential matches the one obtained before with the primary ion. The MPM selectivity coefficient is then defined by calculation of the ratio of the primary ion and interfering ion activity differences in the two experiments. ${ }^{36}$

The other method namely the SSM involves the measurement of two separate solutions, each containing a salt of the determined ion only. The Nicolskii coefficient is then calculated from the two observed emf values. ${ }^{36}$ 
The resulting selectivity coefficients values are given in Table 2. It is immediately obvious from these data, that the proposed Ho(III) sensor is selective with respect to the most of cations. In the case of lanthanide ions the selectivity coefficients are in the order of $5.0 \times 10^{-2}$ or smaller, which seems to indicate that the Ho(III) ions can be determined in the presence of other lanthanide ions. The selectivity coefficients for other cations $\left(\mathrm{Na}^{+}, \mathrm{K}^{+}\right.$, $\mathrm{Mg}^{2+}, \mathrm{Ca}^{2+}, \mathrm{Cu}^{2+}$, and $\mathrm{Pb}^{2+}$ ) are smaller than $7.0 \times 10^{-3}$, and they can not disturb the functioning of the Ho(III) membrane electrode. The surprisingly high selectivity of the membrane electrode for Ho(III) ions over other cations used most probably arises from the strong tendency of the carrier molecule for Ho(III) ions.

Table 2. Selectivity coefficients of various interfering cations for the membrane with the optimum composition

\begin{tabular}{lcclcc}
\hline Ion & $\mathrm{K}_{S e l, M P M}$ & $\mathrm{~K}_{S e l, S S M}$ & Ion & $\mathrm{K}_{S e l, M P M}$ & $\mathrm{~K}_{S e l, S S M}$ \\
\hline $\mathrm{Dy}^{3+}$ & $5.0 \times 10^{-2}$ & $3.5 \times 10^{-2}$ & $\mathrm{La}^{3+}$ & $1.3 \times 10^{-3}$ & $1.1 \times 10^{-3}$ \\
$\mathrm{Nd}^{3+}$ & $8.1 \times 10^{-3}$ & $8.0 \times 10^{-3}$ & $\mathrm{Ca}^{2+}$ & $3.2 \times 10^{-3}$ & $1.7 \times 10^{-3}$ \\
$\mathrm{Tm}^{3+}$ & $2.0 \times 10^{-3}$ & $5.0 \times 10^{-3}$ & $\mathrm{Mg}^{2+}$ & $3.3 \times 10^{-3}$ & $1.8 \times 10^{-3}$ \\
$\mathrm{Sm}^{3+}$ & $3.2 \times 10^{-2}$ & $1.7 \times 10^{-2}$ & $\mathrm{Na}^{+}$ & $6.5 \times 10^{-3}$ & $3.9 \times 10^{-3}$ \\
$\mathrm{Pr}^{3+}$ & $3.0 \times 10^{-3}$ & $1.2 \times 10^{-3}$ & $\mathrm{~K}^{+}$ & $7.0 \times 10^{-3}$ & $4.5 \times 10^{-3}$ \\
$\mathrm{Ho}^{3+}$ & $6.2 \times 10^{-3}$ & $3.5 \times 10^{-3}$ & $\mathrm{Cu}^{2+}$ & $1.7 \times 10^{-3}$ & $1.2 \times 10^{-3}$ \\
$\mathrm{Er}^{3+}$ & $3.5 \times 10^{-2}$ & $3.0 \times 10^{-2}$ & $\mathrm{~Pb}^{2+}$ & $6.7 \times 10^{-3}$ & $2.9 \times 10^{-3}$ \\
\hline
\end{tabular}

Table 3. The lifetime behavior of the $\mathrm{Ho}^{3+}$ membrane sensor

\begin{tabular}{lll}
\hline Period & Slope $/\left(\mathrm{mV}\right.$ decade $\left.{ }^{-1}\right)$ & Limit of Detection \\
\hline 14 days & $19.6 \pm 0.2$ & $8.0 \times 10^{-6}$ \\
1 month & $19.1 \pm 0.3$ & $8.0 \times 10^{-6}$ \\
1.5 months & $18.8 \pm 0.3$ & $9.0 \times 10^{-6}$ \\
2 months & $18.3 \pm 0.2$ & $1.0 \times 10^{-5}$ \\
2.5 months & $18.0 \pm 0.4$ & $1.5 \times 10^{-5}$ \\
3 months & $17.6 \pm 0.3$ & $2.5 \times 10^{-5}$ \\
3.5 months & $17.3 \pm 0.2$ & $4.0 \times 10^{-5}$ \\
4 months & $17.1 \pm 0.4$ & $5.0 \times 10^{-5}$ \\
\hline
\end{tabular}

The dynamic response time of the sensor, being another very important parameter in the evaluation of a sensor, was studied by varying the concentration of a solution from $1.0 \times 10^{-5} \mathrm{~mol} \mathrm{~L}^{-1}$ to $1.0 \times 10^{-2} \mathrm{~mol} \mathrm{~L}^{-1}$ and recording the times needed for the sensor to reach $\pm 1 \mathrm{mV}$ of its equilibrium potential (Figure 5). The response time of the sensor was found to be about 5 seconds.

The proposed Ho(III) membrane electrode was found to work well under laboratory conditions. It was applied as an indicator electrode for the titration of $20.0 \mathrm{~mL}$ of $1.0 \times 10^{-4} \mathrm{~mol} \mathrm{~L}^{-1}$ of $\mathrm{Ho}$ (III) solution with $1.0 \times 10^{-2} \mathrm{~mol}$ $\mathrm{L}^{-1}$ of standard EDTA, and vice-versa. The resulting titration curve is shown in Figure 6. As can be seen from Figure 6, the amount of Ho(III) ions, and EDTA, can be determined with good accuracy.

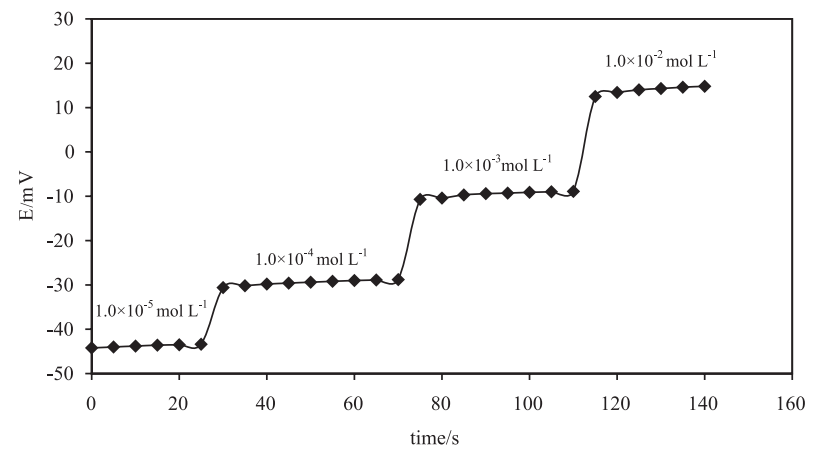

Figure 5. Dynamic response time of the electrode for step changes in the concentration of Ho(III) solution.

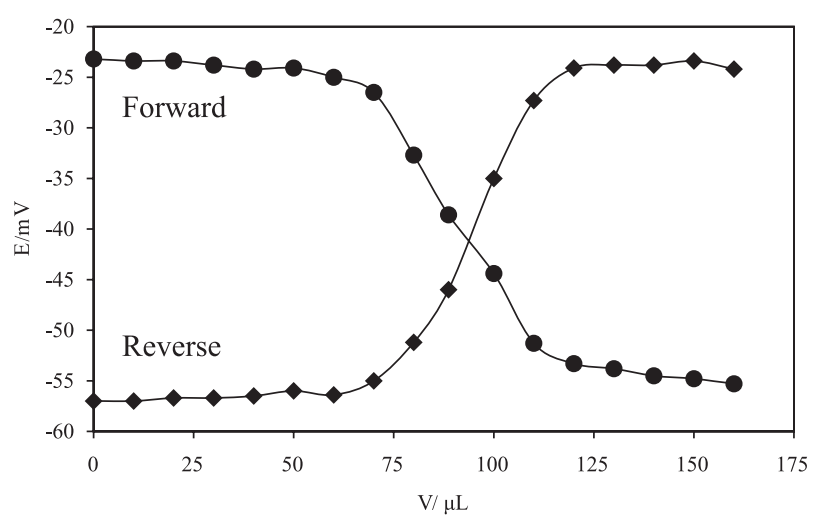

Figure 6. Potentiometric titration curve of $25 \mathrm{~mL}$ of a $1.0 \times 10^{-4} \mathrm{~mol} \mathrm{~L}^{-1}$ Ho(III) solution, with a $1.0 \times 10^{-4} \mathrm{~mol} \mathrm{~L}^{-1}$ EDTA and vice-versa, using the proposed membrane sensor as an indicator electrode.

The proposed Ho(III) membrane sensor was also successfully used to the determination of fluoride ion in three different pharmaceutical samples, and the results of triplicate measurements are given in Table 4. As can be seen from Table 4, there is a good agreement between the declared fluoride content and the determined values.

Table 4. The results of the determination of fluoride in mouth wash solution samples

\begin{tabular}{lcl}
\hline Sample $^{\mathrm{a}}$ & Labeled / (\%) & Found / (\%) \\
\hline 1 & 2.0 & $2.03 \pm 0.04$ \\
2 & 0.2 & $0.22 \pm 0.03$ \\
3 & 1.0 & $0.97 \pm 0.04$ \\
\hline
\end{tabular}

${ }^{\mathrm{a} C h i m i a ~ D a r u ~ C o . ~ T e h r a n, ~ I r a n . ~}$

\section{Conclusions}

The results obtained from the above-mentioned study revealed that a potentiometric PVC-based membrane sensor based on $\mathrm{H}_{2}$ BPB functions as an excellent $\mathrm{Ho}(\mathrm{III})$ selective membrane sensor and can be used for the determination of this ion in the presence of considerable concentrations of common interfering ions. Applicable $\mathrm{pH}$ range, lower detection limit, and potentiometric 
selectivity coefficients of the proposed sensor make it a superior device both compared to other methods used for the determinations of this ion.

\section{Acknowledgment}

The authors express their appreciation to the University of Tehran Research Council for financial support of this work.

\section{References}

1. Hampel, C. A.; Book, R.; The Encyclopedia of the Chemical Elements, Corporation: New York, 1968.

2. Ganjali, M. R.; Rasoolipour, S.; Rezapour, M.; Norouzi, P.; Adib, M.; Electrochem. Commun., 2005, 7, 989.

3. Ganjali, M. R.; Daftari, A.; Qomi, M.; Norouzi, P.; Sens. Actuators, B 2004, 98, 92.

4. Ganjali, M. R.; Daftari, A.; Rezapour, M.; Talanta 2003, 59, 613.

5. Shamsipur, M.; Yousefi, M.; Hosseini, M.; Ganjali, M. R.; Anal. Chem. 2004, 74, 5538.

6. Hassanien, M. M.; Abou-El-Sherbini, K. S.; Mostafa, G. A. E.; Talanta 2003, 59, 383.

7. Ito, T.; Goto, C.; Noguchi, K.; Anal. Chim. Acta 2001, 443, 41.

8. Akhond, M.; Najafi, M. F.; Tashkhourian, J.; Sens. Actuators, B 2004, 99, 410.

9. Ganjali, M. R.; Kiani, R.; Shamsipur, M.; Poursaberi, T.; Salavati-Niasari, M.; Talebpour, Z.; Emami, M.; Electroanalysis 2004, 16, 1002.

10. Gupta, V.; Suresh, J.; Chandra, C.; Anal. Chim. Acta 2004, 486, 199.

11. Shamsipur, M.; Yousefi, M.; Ganjali, M. R.; Anal. Chem. 2000, 72, 2391.

12. Shamsipur, M.; Yousefi, M.; Ganjali, M. R.; Hosseini, M.; Anal. Chem. 2002, 74, 5538.

13. Karami, H.; Mousavi, M. H.; Shamsipour, M.; Yavari, I.; Alizadeh, A. A.; Anal. Lett. 2003, 36, 1065.

14. Mittal, S. K.; Kumar, S. K. A.; Sharma, H. K.; Talanta 2004, 62, 801.

15. Shamsipur, M.; Yousefi, M.; Hosseini, M.; Ganjali, M. R.; Anal. Lett. 2001, 34, 2249.

16. Gaber, A. A. A.; Anal. Lett. 2003, 36, 2585.

17. Ganjali, M. R.; Pourjavid, M. R.; Rezapour, M.; Haghgoo, S.; Sens. Actuators, B 2003, 89, 21.
18. Akhond, M.; Najafi, M. F.; Tashkhourian, J.; Anal. Chim. Acta 2005, 531, 179 .

19. Shamsipur, M.; Hosseini, M.; Alizadeh, K.; Eskandari, M. M.; Sharghi, H.; Mousavi, M. F.; Ganjali, M. R.; Anal. Chim. Acta 2003, 486, 93.

20. Amarchand, S.; Menon, K.; Agrawal, Y. K.; Electroanalysis 2000, 12, 522 .

21. Ganjali, M. R.; Rezapour, M.; Pourjavid, M. R.; Haghgoo, S.; Anal. Sci. 2004, 20, 1007.

22. Shamsipur, M.; Hosseini, M.; Alizadeh, K.; Talebpour, Z.; Mousavi, M. F.; Ganjali, M. R.; Arca, M.; Lippolis, V.; Anal. Chem. 2003, 75, 5680.

23. Ganjali, M. R.; Rahimi, M.; Maddah, B.; Moghimi, A.; Borhany, S.; Anal. Sci. 2004, 20, 1427.

24. Ganjali, M. R.; Tahami, R.; Shamsipur, M.; Poursaberi, T.; Haghgoo, S.; Hosseini, M.; Electroanalysis 2003, 15, 1038.

25. Ganjali, M. R.; Naji, L.; Poursaberi, T.; Shamsipur, M.; Haghgoo, S.; Anal. Chim. Acta 2003, 475, 59.

26. Ganjali, M. R.; Matloobi, P.; Ghorbani, M.; Norouzi, P.; Salavati-Niasari, M.; Bull. Korean Chem. Soc. 2005, 26, 38.

27. Ganjali, M. R.; Ravanshad, J.; Hosseini, M.; Salavati-Niasari, M.; Pourjavid, M. R.; Baezzat, M. R.; Electroanalysis 2004, 16, 1771

28. Shamsipur, M.; Hosseini, M.; Alizadeh, K.; Mousavi, M. F.; Garau, A.; Lippolis, V.; Yari, A.; Anal. Chem. 2005, 77, 276.

29. Amirnasr, M.; Kurt, J.; Schenk, S.; Meghdadi, S.; Inorg. Chim. Acta 2002, 338, 19.

30. Bakker, E.; Bulmann, P; Pretsch, E.; Electroanalysis 1999, 13, 916.

31. Eugster, E.; Gehrig, P. M.; Morf, W. E.; Spichiger, U.; Simon, W.; Anal. Chem. 1990, 63, 2285.

32. Rosatzin, T.; Bakker, E.; Suzuki, K.; Simon, W.; Anal. Chim. Acta 1993, 280, 197.

33. Bakker, E.; Pretsch, E.; Buhlman, P.; Chem. Rev. 1997, 98, 1593.

34. IUPAC Analytical Chemistry Division, Commission on Analytical Nomenclature, Recommendations for Nomenclature for Ion Selective Electrodes.; Pure Appl. Chem. 1976, 48, 127.

35. Umezawa, Y.; Umezawa, K.; Sato, H.; Pure Appl. Chem. 1995, 67, 507.

36. Ganjali, M. R.; Norouzi, P.; Rezapour, M.; Encyclopedia of Sensors, Chapter on "Potentiometric Ion-Selective Sensors", American Chemical Society, 2006, 8, 197.

Received: December 6, 2005

Published on the web: July 25, 2006 